150/1, 195-208., Budapest, 2020

DOI: 10.23928/foldt.kozl.2020.150.1.195

\title{
A hazai földtani szakigazgatás története
}

\author{
HÁMOR TAMÁs
}

Európai Bizottság, Közös Kutatási Központ

\section{The history of the geological administration in Hungary}

\begin{abstract}
The institutional geological public administration has been existing for 170 years in Hungary, supporting the central government for the very beginning, and since the mid twentieth century, it has been part of the public administration as an independent competent professional authority. The ratio and thematics of the authority and co-authority scope and sphere changed continuosly, as well as the name, structure and legal status of the entities in question. This latter also reflects the evolution of the broader political context. The dilemma of central vs. de-centralised public administration presents all along its history in Hungary. Nevertheless, in case of the geological authority which requires and involves a significant information and knowledge base, the weakening work relations and communication between the first-instance and the second-instance geological authorities, and the decreasing capacities in information service, may endanger the effective and client-friendly good governance. Due to the transposition of the relevant Community legislation of the European Union and the successful professional legislation making in Hungary over the last few decades, the embedding of geology into national legislation is good, it has been increasing until 2008-2012. The safeguarding of this good practice and maintaining the institutional implementation framework can be a rational political objective.
\end{abstract}

Keywords: geological authority, geological public administration

Összefoglalás

Az intézményesített földtan 170 éve van jelen Magyarországon, a kezdetektől fogva támogatva az államigazgatást, majd a 20. század közepétől külön hatóságként a hazai közigazgatást. A hatósági és szakhatósági jogkörök aránya és tematikája folyamatosan változott, csakúgy, mint a kérdéses intézmények neve, szervezete és jogállása. Ez utóbbi jól tükrözi a tágabb politikai kontextus idôbeli változásait is. A centralizáció-decentralizáció dilemmája végig jelen van a hazai közigazgatás történetében, azonban a földtan esetében, amely jelentős adat- és információigényú, az első és másodfokú földtani hatóság kommunikácójának és munkakapcsolatának gyengülése, az információszolgáltatási képességek csökkenése nehezítheti a hatékony és ügyfélbarát ,jó kormányzást”. A földtan jogszabályi „,beágyazottsága” az elmúlt évtizedek szakmai jogalkotói munkájának és az Európai Unió vonatkozó közösségi joga átültetésének köszönhetôen jó, 2008-2012-ig folyamatosan nőtt. Ezt és a végrehajtás intézményi eszközrendszerét megóvni észszerú szakpolitikai cél lehet.

Tárgyszavak: földtani hatóság, szakigazgatás, közigazgatás

\section{Bevezetés}

Az elmúlt két év a hazai földtanban két évfordulót is hozott, 2018-ban lett 170 éves a Magyarhoni Földtani Társulat (MFT) és 2019-ben lett volna 150 éves a Földtani Intézet. Az elmúlt két-három évben teljesedett ki a magyar közigazgatás sokadik reformja is, amely jelentôs hatással bír a földtani intézményrendszerre és szúkebb értelemben a földtani hatóság hatáskörére és szervezeti rendjére.
A fenti aktualitásoktól is indíttatva, jelen tanulmány bemutatja a földtan és a földtani intézményrendszer múlt-és jelenbeli szerepét a magyar közigazgatásban, és a fontosabb közelmúltbeli időkivágatokban röviden elemzi a mindenkori földtani hatóság hatásköreit. A dolgozat kísérletet tesz a szakma jogszabályi meghatározottsága változásainak kvantitatív jellemzésére és a hatásköri tematikák történelmi trendjeinek vázolására. Az intézményi átszervezések időbeli dinamikájából a tágabb közigazgatási és politikai 
kontextusra is megpróbál következtetéseket levonni a szerző. A földtani hatóság szervezetében és hatáskörében többször is összefonódott a bányászati szakigazgatással, de ez utóbbinak a bemutatása nem a tanulmány tárgya. Ezt számos kitûnő szerző megtette már (IzSÓ 2010, 2019; NÉMETH 1993; TÁRKÁNY SzỨCS et al. 1970; VÖRÖS et al. 1985, ZsÁMBOKI 1982; ZsARNAi 1986), ezért a cikk kivonatosan utal erre a kapcsolatra. A szúkebb földtanon belül nagy hagyománya van a szakmatörténeti munkáknak (pl. BREZSNYÁNSZKY 2019, HÁlA 1994, HÁMORNÉ VIDÓ 2002), és az egyes földtani hatóságokról is születtek monografikus múvek (pl. MoRvai 1992), de teljes tanulmány eddig nem foglalkozott a földtani szakigazgatás 170 évével.

A jogszabályok hazánkban gyakran módosulnak, ezért a részletes hatásköri listák bemutatására a cikk terjedelmi okokból nem vállalkozhat. A 20. század végéig terjedő időszakot részletesen bemutatják BöcK \& SzONTAGH (1900), VENDL (1958), FÜlÖP \& TASNÁdi KUBACSKA (1969), ZELENKA (1993), Dudich (1994), Hála (1994), Hámor (1996), és HÁMOR \& REZESSY (1997) munkái.

A földtan társadalmi és politikai elfogadottságában és nemzetgazdasági hasznosulásában különös jelentősége van jogszabályi és közigazgatási beágyazottságának. A szerző az elmúlt 35 évben e meggyőződésében munkálkodott, és ajánlja e munkát mindazon kollégáknak, akik osztották e nézeteit és támogatták ez irányú erôfeszítéseit.

\section{Módszertan}

A történelmi áttekintés elsôsorban szakirodalmi kutatáson alapul, valamint a Wolters Kluwer kiadó Corpus Juris Hungarici történelmi jogtárának szókeresési szolgáltatásával kinyert adatokon. Az egyes időkivágatok egykori földtani hatásköri listáinak kigyújtését a Wolters Kluwer kiadó jogtára „időgép” funkciójának használata tette lehetővé. Ugyancsak ez a szolgáltatás, valamint a Nemzeti Jogtár (njt.hu) volt alkalmas a „,földtan”, ,geológia”, ,ásvány” tárgyszavak évek szerinti lekeresésére.

Az európai kitekintésben a szerző saját munkáira (HÁMOR 1999, 2004, 2014b, 2016) és az EU Nyersanyaginformációs Rendszerének szolgáltatásaira (https://rmis. jrc.ec.europa.eu/) támaszkodott.

\section{Eredmények}

\section{Történeti áttekintés}

\section{Az előzmények (1848-ig)}

A földtan története a 18. századig egybeforrt a bányászat történetével (FüLÖP 1984). A magyar bányajog történetét TÁRKÁNy SzÛ́Cs et al. (1970) és ZsÁMBOKI (1982) munkái részletesen tárgyalják. A bányászatot számos különböző szintú írásbeli rendelkezés szabályozta szinte a honfoglalástól, a Miksa-féle bányarendtartás (1573) volt az első egységes „,bányatörvény” 1854-ig. 1790 és 1844 között több kísérletet tettek az országos bányatörvény létrehozására. Az 1843/44. évi országgyúlés törvényjavaslatként tárgyalta a bányatörvényt, amelyet mindkét ház elfogadott, de a király nem szentesítette.

1854-től 1945-ig az ipari fejlődést hatékonyan szolgálta a 173. számú császári nyílt paranccsal kibocsátott osztrák általános bányatörvény, amelyet módosításokkal 1945-ig, formailag egészen 1960-ig alkalmazni kellett. A legfontosabb „fenntartott ásványok” kutatását és kitermelését csak engedély alapján lehetett végezni. Ez az első olyan jogszabály, ahol a földtani kutatás, ha nem is ilyen néven, de elkülönítetten megjelenik. Ez időben bányajogunk további jogforrását adta az 1911. évi VI. tc. az ásványolajfélékrôl és a földgázról és az 1911. évi VII. tc. a káliumsókról, mely ásványi nyersanyagokra az állam kizárólagos bányászati jogot biztosított magának, de lehetôvé tette, hogy a kormány a parlament jóváhagyásával a kutatás, kitermelés és értékesítés jogát meghatározott időre, meghatározott feltételek mellett másokra is átruházhassa.

\section{A földtani közigazgatás kezdetei (1848-1945)}

A földtan mint önálló tudomány kialakulása a 18. századra tehető. Az 1735-ben alapított selmecbányai „Berg Schola”ban a kezdetektől oktattak ásvány-kőzettani és bányaföldtani ismereteket, a geológiának a rendszerbe foglalását A. G. WERNER freibergi tanárnak tulajdonítják, aki 1780-tól tartott előadásokat ,geognosia” néven. Európában sorra alakultak a földtani tudományos társaságok (Anglia: 1807, Franciaország: 1830, Skócia: 1834, Németország: 1848), majd megalapították az elsô állami földtani kutató intézeteket (Anglia: 1835, Kanada: 1841, India: 1846, Ausztria:1849).

Magyarország kis késéssel követte az európai példát (VENDL 1958). A Magyar Orvosok és Természetvizsgálók 1847. évi nyolcadik soproni vándorgyúlésén elfogadták ZIPSER KERESZTÉLY András javaslatát, aki önálló „földismei” és bányászati egyesület alapítását szorgalmazta. A Magyarhoni Földtani Társulat (MFT) alakuló programját 1848. január 3-án Videfalván írták alá, de az első Közgyưlésre az 1848-49. évi szabadságharc miatt nem került sor. A program fő pontja volt az ország hasznosítható ásványi nyersanyagainak felkutatása, a haza földtani térképének elkészítése, ásvány-kőzettani és őslénytani gyưjtemény létrehozása a Nemzeti Múzeumban, a magyar föld történetének megismerése. 1849. december 1-én kezdte meg múködését a bécsi Cs. K. Birodalmi Földtani Intézet, amely a birodalom területének földtani megismerését tûzte ki céljául. E feladat megkívánta a meglévő (pl. Tirol, Voralberg) földtani magánegyletek közremúködését és újak alakítását is. Az 1856-ban elfogadott új alapszabály révén az MFT tudományos kapcsolata a bécsi intézettel ezután lett szorosabb. Az MFT megalakulása után eltelt húsz év alatt bebizonyosodott, hogy az esetleges és területileg szétszórt kutatások nem teljesítik az alapításkori célokat. SzABó József (az MFT titkára), ZsIGMONDY Vilmos bányamérnök és FEST Imre államtitkár GOROVE István m. kir. földmívelés-, ipar- és kereskedelemügyi miniszternek referáltak, aki 1868. január 16-dikán felkérte a Társulatot javaslat kidolgozására. A M. Kir. Földmívelés-, Ipar- és Kereskedelemügyi Minisztérium keretében 1868 júliusától 
1869. június 18-ig elkülönült Magyar Királyi Földtani Osztály múködött.

Ez utóbbi napon Ferenc József aláírta a Magyar Királyi Földtani Intézet alapításáról szóló oklevelet, amelynek alapszabálya a következő célokat tűzte ki:

„a) a magyar korona országainak részletes földtani felvétele és e felvétel eredményének a tudomány, a földmívelés és az ipar igényeinek megfelelö módon való megismertetése,

b) a magyar államterület általános és részletes földtani térképeinek készítése és kiadása,

c) a magyar államterület földtani alkotásában résztvevó képzoodményeket és az azoknak jellegét elótüntetö kózet és öslénytani gyütemények felállítása,

d) talaj, ásvány és kơzet vegyelemzése mezógazdasági, bányászati és ipari tekintetben”.

A múködési szabályzat előrevetíti a földtan államigazgatási szerepét: „Ezen rendes felvételeken kivül valamely minisztérium, vagy kincstári bányászati hatóság megkeresésére egyes bányászati, vagy más ipari tekintetben közgazdászati fontossággal bíró vidékek földtani átkutatása, a miniszter engedelme alapján, az intézet által megtörténhetik, ha a felvételek rendes sorának megtartása mellett ezen vidékek földtani felvétele csak késóbbi idókben várható volna.” A Földtani Intézet és a bányakapitányságok ,összes bel-és személyzeti ügyeit" a Földmívelés-, Ipar-és Kereskedelemügyi M. Kir. Minisztérium Bányaipari Osztálya látta el. A földtani kutatások költségeinek állami fedezetéról az 1885. évi XIV. törvénycikk intézkedett: ,Minden szabadkutatás (zárt kutatmány) után felügyeleti illetmény fizetendő." Ennek célja volt a bányaigazgatás költségeinek fedezése és ,a nem komoly célú bányászat mérséklése”.
Az MFT tevékenysége megerősödött a Földtani Intézet megalakulásával, és a rivalizálás helyett együttmúködés alakult ki. Az MFT soha nem épült be az államigazgatási hierarchiába, de többször látott el országos jelentőségű feladatokat kormányzati megbízásból. Így az MFT hozta létre az elsô földrengés-megfigyelő hálózatot a Magyar Tudományos Akadémia (MTA) támogatásával 1881-ben, többször nyilvánított szakvéleményt kormányzati megkeresésre közérdekú ügyekben, és egy időszakban az MFT adott ki földtani szakértői engedélyeket.

A Földtani Intézet történetét BöCKH \& SzONTAGH (1900), FülÖP \& TASNÁDI KubACSKA (1969), Dudich (1994), Hála (1994) és BREZSNYÁNSZKY (2019) munkái részletesen tárgyalják, ezért e dolgozat csak a tárgy szempontjából fontos mozzanatokat emeli ki. A földtani szakigazgatás szereplőinek történeti áttekintését az 1. ábra adja. HANTKEN Miksa igazgatósága alatt sor került a nagyberuházások földtani megalapozására, pl. az ebben az időben épült 4000 km vasútvonal nyomvonalának földtani megalapozására. A századvégi gazdasági fellendülés az intézettől kért szakvélemények ugrásszerúen megnövekedett számában is tükröződött. Így készült például a budai keserúvíz forráscsoport védőterületéről és Pécs város vízellátásáról szakvélemény.

1882-1908 között, BöcKH János igazgatósága alatt a tevékenység jelentôsen fejlődött és egyben differenciálódott. Az 1885. évi XXIII. vízjogi törvény hatósági szakértői jogkörrel ruházta fel az intézetet. A gyógy- és ásványvizek védelme, a vízellátási problémák megoldása, az artézi kutak létesítésének engedélyezése és szakszerû telepítése ügyében megszaporodtak a megkeresések (káposztásmegyeri, dunakeszi és fóti vízmúvekről készített szakvélemények).
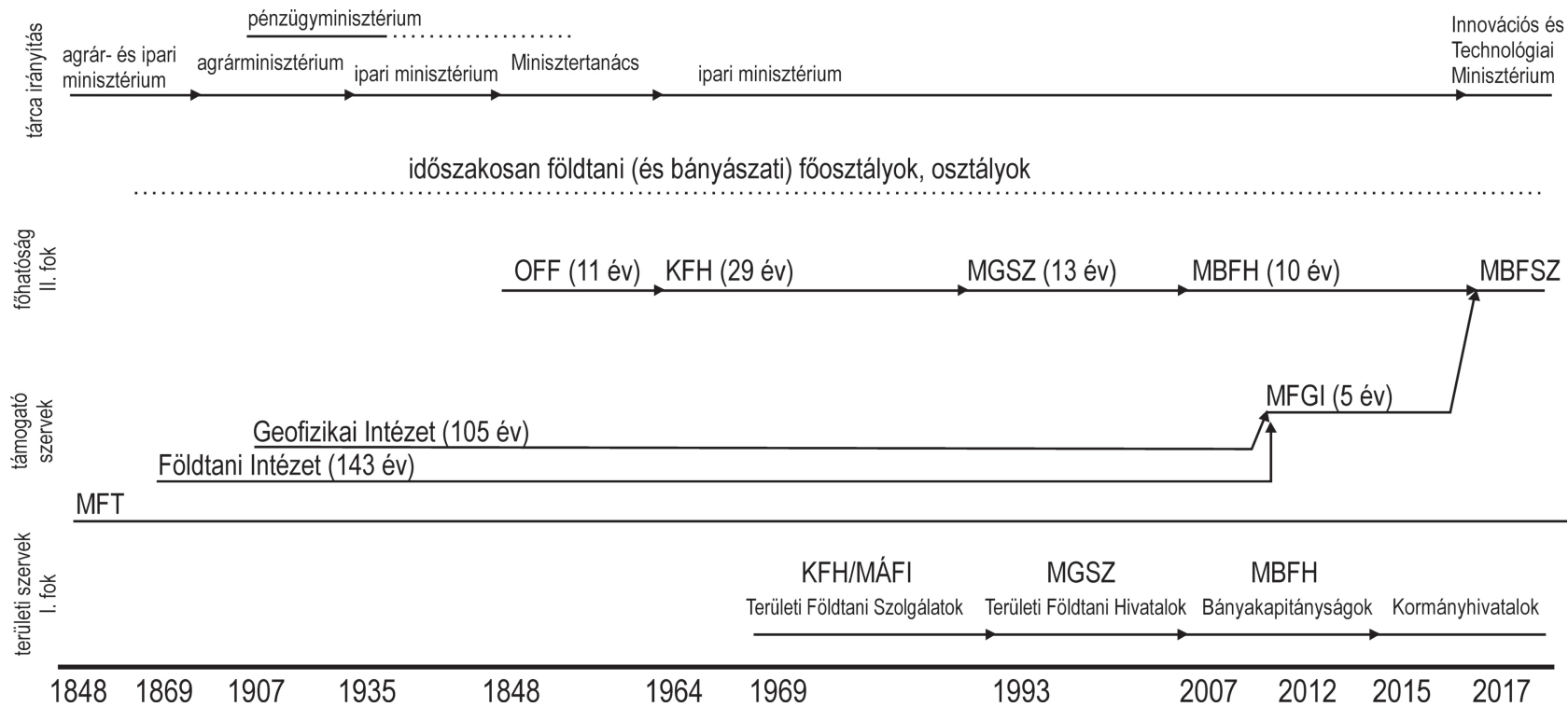

1. ábra. A hazai földtani intézmények államigazgatási szerepkörrel, történelmi áttekintés (az időlépték torzitott)

KFH: Központi Földtani Hivatal, MÁFI: Magyar Állami Földtani Intézet, MBFH: Magyar Bányászati és Földtani Hivatal, MBFSZ: Magyar Bányászati és Földtani Szolgálat, MFT: Magyarhoni Földtani Társulat, MGSZ: Magyar Geológiai Szolgálat, OFF: Országos Földtani Főigazgatóság

Figure 1. A historical review of geological entities with role in public administration in Hungary (the time scale is distorted)

KFH: Central Office for Geology, MÁFI: Geological Institute of Hungary, MBFH: Mining and Geological Office for Hungary, MBFSZ: Mining and Geological Survey of Hungary, MFT: Magyarhoni Földtani Társulat, MGSZ: Geological Society of Hungary, OFF: National Directorate General Geology 
Az intézet fontos szerepet vitt a kőolajkutatásokban, mert állami támogatást a kőolajkutató társaságok az intézet pozitív szakvéleménye birtokában kaphattak. Intézeti feladat volt a kutató létesítmények ellenőrzése is. Budapest környékén ekkor vizsgálták meg a környező községek földtani építésalkalmasságát, amely a mai agglomeráció alapjait képezi. Ugyancsak szakvéleményezték a főváros lejtőcsuszamlással veszélyeztetett építési körzeteit.

A filoxérajárvány után az intézet feladata lett a szőlőtelepítésre alkalmas immunis talajú területek kijelölése. 1890-ben a Földmívelésügyi Minisztérium támogatásával felállították az agrogeológiai osztályt (Agronóm Geológiai Osztály). 1885-ben jelent meg a „Mü- és építóipari tekintetben fontosabb magyarországi közetek részletes katalógusa" és ,Azagyag, üveg, cement és ásványfesték iparnak szolgáló magyarországi nyersanyagok részletes katalógusa”, amelyek a mai ásványvagyon-nyilvántartás elsô kezdeményei. Kiadásra került „A magyar korona országainak területén létezó kóbányák ismertetése", amely az első hazai bányakataszter. Kapcsolat épült ki a Folyammérnöki és Kultúrmérnöki Hivatalokkal és Iparkamarákkal. 1890-től vált el az ipari és kereskedelmi tárca a földmúvelésügytől, és a bányászati szakigazgatás az előbbihez került.

A századfordulótól megnőtt a Pénzügyminisztérium megkereséseinek a száma, főként a kőolajkutatás tekintetében. 1908-ban id. Lóczy Lajos igazgatósága alatt az alkalmazott földtani tevékenység növekedése megkövetelte a gyakorlati geológiai osztály felállítását.

1907-ben megalakul EöTvös Loránd geofizikai kutatócsoportja, amely a Vallás és Közoktatásügyi Minisztérium 28762/1907. sz. határozata szerint évi 60000 koronát kapott az állami költségvetésből a ,báró Eötvös Loránd-féle csavarási ingakisérletek támogatására". Ezzel párhuzamosan az Országos Meteorológiai és Földmágnességi Központi Intézet átadta földfizikai feladatait a csoportnak, és EöTvös Loránd halála után, 1919. november 18-tól a kutatócsoport a múszerekkel egyetemben átkerült a Pénzügyminisztérium Bányakutatási Osztályához. 1910-ben a Pénzügyminisztérium Bányaföldtani Osztályt állított fel, amely elsősorban az állami monopóliumot képező kőolaj, földgáz, kősó és kálisó kutatásával foglakozott. Az intézet felmérte Magyarország kőszén- és érckészletét, amely 1916-ban jelent meg. Fontos volt az intézet szakhatósági szerepében az 1913. évi „A vízjogról szóló törvény kiegészítésérôl és módosításáról” kiadott XVIII. sz. törvénycikk és az annak végrehajtása ügyében kiadott 1200. sz. FM-rendelet, amelyek meghatározták az intézet hatósági szakértői szerepkörét, és az artézikút fúrásokat és a vízmúvek védőterületeinek kijelölését földtani szakértői javaslattól tették függôvé. Ez a hidrogeológiai szakértői tevékenység az 1960-as évekig jelentős mértékú feladatot jelentett.

A Tanácsköztársaság idején az intézet a Földmívelésügyi Népbiztosság felügyelete alá tartozott. A vízföldtani szakvéleményezés (pl. lillafüredi, debreceni, szombathelyi vízkutatás) és a mérnökgeológiai kutatások (budapesti földalatti fejlesztési terve) az első világháború után is változatlan intenzitással folytak. 1929-ben BöcKH Hugó a Földtani Intézet igazgatóságát államtitkári (!) rangban átvéve első lépésként a Pénzügyminisztérium Bányaföldtani Osztályát az intézetbe olvasztotta. Kijelölte a feladatokat: az intézet egyik része a Pénzügyminisztérium által meghatározott feladatokon, a másik a Földmívelésügyi Minisztérium által előírt agrogeológiai feladatokon dolgozott, a harmadik csoport pedig a tudományos jellegú munkákat végezte. Megszervezte a Földtani Tanácsadó Bizottságot, amelynek feladata az éves kutatási tervek véleményezése volt. Az ő és utóda, ifj. Lóczy Lajos igazgatósága alatt teljesedett ki az ásványi nyersanyagkutatási tevékenység, és folytatódtak a gyakorlati geológiai kutatások. Az intézetben megszervezték a vízügyi nyilvántartást.

Jellemzi az intézet állami elismertségét, hogy igazgatója a Székesfóvárosi Törvényhatósági Bizottság tagja (1920. évi IX. törvénycikk) és az 1927. évi XIII. tc. értelmében alakult Országos Ösztöndíjtanács tagja volt. Az 1929. évi XI. tc. a múzeum-, könyvtár- és levéltárügy némely kérdéseinek rendezéseiről tárgyi hatályában nevesíti a földtani és őslénytani ásatásokat. Az 1935. évi IV. tc. 217 §-a rendelte el a Természetvédelmi Tanács felállítását, amelynek a 4235/ 1949. (IX. 15.) MT-rendelet szerint tagja volt az intézet igazgatója is.

A földmívelésügyi miniszter a pénzügyminiszterrel egyetértésben a 74477/1930. II. 4. sz. rendeletében kimondta, hogy a bányászati kutatások programját évenként a Pénzügyminisztérium Bányászati Főosztálya az intézet javaslatának figyelembevétele alapján terjeszti a pénzügyminiszter elé. 1935 júliusában megalakult az Iparügyi Minisztérium X. osztálya, amely az elsô földtani főhatóságnak is tekinthető. A Pénzügyminisztériumtól ide kerültek a bányászati kutatások, a Geofizikai Intézet és az ekkor a Kereskedelemügyi Minisztérium irányítása alatt álló kutatások is (kaolin, tűzálló agyagok stb.).

Ennél a történelmi időszaknál meg kell említeni az 1825-ben megalakult Magyar Tudományos Akadémiát. Az MTA-n a földtan bevezetése SzABó Józsefhez füződik, aki az első geológus akadémikus volt a Matematikai, Természettudományi és Orvostudományi Osztályon. SzÁDECZKYKARDOss Elemér közbenjárására 1965-ben a Múszaki Tudományos Osztályból vált ki az MTA X. Föld- és Bányászati Tudományok Osztálya (1990-től az MTA X. Földtudományok Osztálya), amelyet gyakran bevontak a jogszabályelőkészítés tárcaegyeztetési eljárásaiba, és számos állásfoglalást adott kormányprogramokhoz, koncepciókhoz.

\section{Az átszervezések és államosítás időszaka (1945-1964)}

A II. világháborút követően az 12.200/1945. MB-rendelet és az 1946. évi XIII. törvény alapján a szénbányászat, az 1948. évi XIII. törvény alapján a bauxitbányászat, a bányászat többi ágazata pedig az 1948. évi XXV. és az 1949. évi 20 tvr. alapján került államosításra. Az 1949. évi XX. törvény az Alkotmány kimondta, hogy „a föld méhének kincsei és a bányák az egész nép vagyonaként az állam tulajdonát képezik". Az új, egységes magyar bányatörvény 
előkészületei 1957-ben indultak meg, az Országgyúlés 1960. évi III. törvényként fogadta el. A bányászat múszaki felügyeletét, a bányászat által veszélyeztetett állampolgári érdekek, a bányavagyon és részben az ásványi nyersanyagok védelmét az Országos Bányamúszaki Főfelügyelőség látta el. Emellett alakultak meg az elsô fokon eljáró kerületi bányamúszaki felügyelőségek, amelyek területi illetékessége különbözött a megyei tagolástól, de bizonyos ügyekben egyes felügyelőségek országos hatáskörrel is rendelkeztek.

Ezeket az éveket a közigazgatásban a kapkodás, a végrehajtatlan jogszabályözön, a kérészéletû́ karrierek és intézmények jellemezték. Az időszakkal foglalkozó kutatók munkáját egymásnak ellentmondó annalesek, titkos kormányhatározatok és fantom intézmények nevei nehezítik. A 9677/1947. GF. sz. határozat (GF HT 1947. XI. 26. 2. sz.) javasolta a Központi Talajkutatási Intézet felállítását az Iparügyi Minisztérium fơhatóságával. Ezt az IpM Bányászati és bányászati kutatási osztálya, a Pénzügyminisztérium Jövedéki mélykutatási ügyosztálya, a Földtani Intézet (az agrogeológia kivételével) és a Geofizikai Intézet összevonásával kellett volna létrehozni, amely terv nem valósult meg. Egy éven át ,létezett" a Tőzzegkutató Intézet a Földtani Intézet keretén belül, amelyet az 1060/1948. GF. sz. határozat (GF HE 1948. V. 20. 20. sz.) 1948. július 1-i hatállyal hozott létre, és a 795/1949. GF sz. határozat (GF HT 1949. IV. 7. 14. sz.) szüntetett meg beleolvadással az akkor alakult Bányászati Kutató Intézetbe (KBFI). 1948. augusztus 1. után a Földtani Intézet főfelügyeletét széles hatáskörrel (földtani kutatás, vízügy, felszíni és mélyépítészeti létesítmények stb. tekintetében) az Iparügyi Minisztérium IV/2. Bányászati osztálya látta el. A 9050/1948. (IX. 5.) kormányrendelet ekkor a bányászatot, a bányászati kutatást és tôzegkitermelést az iparügyi miniszter egységes irányítása alá helyezte. Rendelkezett továbbá a Talajtani Intézet létrehozásáról, amely a Földtani Intézetból vált ki és maradt a földmúvelésügyi miniszter felügyelete alatt (végül Agrokémiai Intézet néven alakul meg 1949-ben). Intézkedett a rendelet a Bányászati Kutatási Tanács felállításáról, amelyben véleményezési és javaslattételi joggal a Földtani és a Geofizikai Intézet delegáltja is részt vett. Az 1946. évi XIII. törvénycikk szerint a Földtani Intézet igazgatója az Országos Szénbányászati Szaktanács tagja volt.

A 3600/1949. (IV. 23.) sz. kormányrendelet még ipari kutató intézetekként említi a Földtani és a Geofizikai Intézetet. Az ezt módosító 4147/1949. (VII. 13.) sz. kormányrendelet azonban mindkét intézetet a Földtani és Bányászati Kutatási Központba vonta össze. A Nehézipari Minisztérium felügyelete és az MTA tudományos irányítása alatt múködő szervezet ügykörébe tartozott a földtan és a bányászat terén a kutatások összehangolása. 1950-tôl a földtani főfelügyeletet a Bánya- és Energiaügyi Minisztérium (BEM) Földtani Fóosztálya látta el. A bánya- és energiaügyi miniszter 30/1951. (I. 7.) BEM-rendelete az altalajkutató, mélyfúró, bányakutató és feltáró múveletekkel kapcsolatos adatszolgáltatásról értelmében minden vállalat köteles volt a tevékenysége során nyert földtani és múszaki adatokat a Földtani Intézet részére megküldeni. 1953-ban a kormány megszüntette a BEM Földtani Fóosztályát, és felállította az Országos Földtani Fóigazgatóságot (OFF), amely nagyobb önállóságot kapva a Minisztertanács alatt országos hatáskörú szervként látta el kibővített feladatkörét: az országos nyersanyagbázis vonatkozásában a koordinációs tevékenységet, a földtani és geofizikai kutatások irányítását és az ország ásványvagyona feletti ellenőrzést (1024/ 1955. (II. 20.) MT-rendelet, 1051/1956 (VI. 3.) Mt-határozat). Az átszervezés azonban még ugyanabban az évben folytatódott. A BEM-t beolvasztották a Nehézipari Minisztériumba, és az Országos Földtani Fớigazgatóság önállóságát megszüntetve a Nehézipari Minisztérium Földtani Igazgatósága néven szervezték át. 1954-ben azonban az igazgatóság már a Szénbányászati Minisztérium alá tartozott.

Ez idő alatt a körülményekhez képest zavartalanul folyt a Földtani Intézetben a szakvéleményezési munka. Elkészült a mélyvezetéses Budapesti Földalatti Vasút mérnökgeológiai tervezése, a dunai vízierômú hidrogeológiai vizsgálata és 1953 végén 33 kötetben az országos nyersanyagkataszter, a jelenkori éves ásványvagyon nyilvántartás alapja.

Az 1024/1955 (II. 20) MT-határozat az OFF 1955. február 1-jei hatályú (ismételt) felállításáról rendelkezik. Ez, mint országos hatáskörú szerv a Minisztertanács közvetlen felügyelete alá tartozott, a fóigazgatót és helyetteseit is a Minisztertanács nevezte ki. Ugyanezen a napon alakult meg az Országos Bányamúszaki Felügyelőség. Az 1051/1956. (VI. 3.) MT-határozat rendelkezik az OFF széles hatósági jogkörérôl és feladatairól, ez lényegében engedélyezési és végrehajtás ellenőrzési jogkörrel ruházta fel minden földtani és ásványi nyersanyag kutatás tekintetében. Egyben rendelkezett a határozat, hogy az összes 10 méternél mélyebb feltárás létesítését tervezésükkor az OFF-nek be kell jelenteni. A 2204/1955. (IX. 10.) MT-határozat létrehozta az Országos Ásványvagyon Bizottságot, amelynek elnöke az OFF elnöke volt. Az 1024/1955. (II. 20.) Mt-határozat létrehozta a Múszaki Tanácsot, amelyet a 2203/1955. (IX. 10.) Mt-határozat Földtani Tanácsra változtatott. Az OFF közvetlenül irányította a Földtani és a Geofizikai Intézetet, valamint a Földtani Kutató és Fúró Vállalatot.

A vízügyi szakhatósági jogkör leválásának elsô jeleként 1956-ban a Földtani Intézet Vízügyi Osztályától az Országos Vízügyi Fóigazgatóság vette át az artézi kút szakvéleményezés feladatkörét. Ugyanakkor a 11/1961. (VE. 8.) EüM-OVF együttes utasítás a közcélú vízvezetéki ivóvízellátásra szolgáló víznyerôhelyek védôterületérôl és védősávjáról az eljáró hatóságok közt említi első fokon a Földtani Intézetet, másodfokon az OFF-t.

\section{A konszolidáció évei, Központi Földtani Hivatal (1964-1993)}

A Központi Földtani Hivatal (KFH) 1964. július 1-én alakult meg az 1013/1964. (V. 4.) kormányhatározattal, amely rögzíti a KFH hatáskörét, szervezetét és múködését. A jogszabályban meghatározott feladatok és hatáskör hasonlatos az OFF-éhez, azonban nagyobb hangsúlyt kap az ásványvagyon-gazdálkodás. A KFH a Földtani Intézet bevonásával elkészítette az ország ásványi nyersanyagkészlet 
mérlegeit, és földtani szempontból ellenőrizte az ásványvagyon gazdálkodási szabályok betartását. A jogszabály felhatalmazza a KFH elnökét a hatáskörébe tartozó ügyekben országos érvényú utasítás kiadására. A KFH országos hatáskörú szervként közvetlenül a kormány alá tartozott, de ezt a felügyeleti jogkört késóbb az 1003/1967. (IV. 22.) kormányhatározat és a 2016/1967. (IV. 22.) kormányhatározat értelmében a nehézipari miniszter gyakorolta. A KFH önálló költségvetési fejezetben gazdálkodott, elnökét a Kormány nevezte ki (1007/1968. (III. 24.) kormányhatározat).

Az Országos Ásványvagyon Bizottság (OÁB) a KFH keretén belül múködött, tevékenységét a 2015/1965. (VI. 4.) kormányhatározat módosította, majd 1970-ben átszervezték. Feladata volt jóváhagyni a kutatási programokat, az éves készletmérlegeket, kidolgoztatta a gazdasági értékelés alapjait, állást foglalt bányatelek-módosítási, -bezárási kérdésekben és meghatározta az ásványvagyon-védelem elveit.

A KFH felügyelete alá tartozott a Földtani és a Geofizikai Intézet. A KFH területi szervekkel nem rendelkezett. Kapcsolatot tartott a bányavállalatok földtani szolgálataival. Ezeknek azonban államigazgatási hatásköre nem volt. A 9/1970. (NIM. E. 10.) NIM (Nehézipari Minisztérium) utasítás sorolta fel azokat az állami vállalatokat, amelyeknek kötelező volt földtani szolgálat fenntartása. Itt nemcsak NIM vállalatok, hanem Építés- és Városfejlesztésügyi Minisztérium (ÉVM) és Mezőgazdasági és Élelmezésügyi Minisztérium (MÉM) szervek, sốt a települési tanácsok bányászattal foglalkozó vállalatai is szerepeltek.

A KFH elnöke felügyeleti és ellenőrzési jogkörét a 15/1965. (NIM. É. 30.) KFH-utasítás állapította meg, amelyet az 1007/1964. (III. 21.) kormányhatározat alapján adott ki. Hatósági jogkörét az 1/1968. (VI. 8.) ÁH-rendelkezés 1. sz. melléklete a földtani kutatással kapcsolatos egyes szolgáltatások tekintetében határozta meg. Az 1/1968. (I. 16.) kormányrendelet a KFH elnökét felhatalmazta gazdasági bírság kiszabásának indítványozási jogával. A KFH elnöke a 24/1971. (VI. 8.) kormányrendelet felhatalmazása alapján földtani szakértői tevékenységekre jogosító engedélyeket adott ki.

A KFH elnöke vezette a Külföldi Földtani Kutatások Tárcaközi Bizottságát, a Ritkafém Tárcaközi Bizottságot és az Országos Geofizikai Múszerbizottságot. A KFH az 1960. évi bányatörvényben és módosításaiban mint központi földtani hatóság nevesítve volt. A bányatörvény hatálya alá tartozó eljárásokban részt vett szakhatóságként, így például kivett helyen folyó kutatás engedélyezésében, szövetkezeti bányászat engedélyezésében, bányatelek megállapítási eljárásban, bányaüzem szüneteltetési és megszüntetési ügyekben. Határozatszerúen adta ki a bányatelepítéshez szükséges megkutatottsági nyilatkozatot, de tényleges hatósági jogköre csak a kutatások engedélyezésében volt.

A KFH az 1960. évi III. törvény a bányászatról és a végrehajtására kiadott 9/1961. (III. 30.) kormányrendelet hatálya alatti tevékenységeken túl szakhatóságként más eljárásokban is részt vett. Az 1964. évi törvény a vízügyről végrehajtási rendelete a 32/1964. (XII. 13.) kormányren- delet és a 11/1965. (VII. 11.) kormányrendelet a vízgazdálkodásnál és az ásvány, illetve gyógyvízkutatásnál, a 7/1986. (VII. 10.) EüM-rendelet a gyógybarlangok létesítésénél nevesíti a KFH-t szakhatóságként. Ugyanakkor a KFH megalakulása egybeesik a földtani intézmények térvesztésével a vízügyi intézményekkel szemben. 1963-ban az Országos Vízügyi Hivatal átvette a vízkutatás teljes feladat- és hatáskörét, sốt az Országos Vízföldtani Adattárat is.

Az 1980. évi I. törvény az atomenergiáról, valamint a 7/1988. (VII. 20.) SZEM-rendelet az atomerômúvi és a radioaktív hulladék elhelyezéssel kapcsolatban nevesíti a KFH-t. Az 1982. évi 4. törvényerejú rendelet a természet védelméról és a végrehajtására kiadott 8/1982. (III. 15.) MTrendelet a védetté nyilvánítási eljárásban a KFH részvételét írta elő. Az 1976. évi II. törvény az emberi környezet védelméről végrehajtására kiadott 1003/1979. (II. 6.) MT-határozat szerint a KFH elnöke ellátja az alapkőzet és az ásványvagyon védelmével kapcsolatos tevékenységek ágazati irányítását.

Építésügyet érintett a bányatörvény 49 . $§$-a, hogy a települések területrendezési terveinek megállapításánál a földtani szempontból értékes területeket figyelembe kell venni, sốt szükség esetén területfelhasználási (1/1968. (I. 11.) ÉVM-rendelet), illetve építési (2/1962. [IV. 30.] EM-PMrendelet) korlátozásokat lehet életbe léptetni. A 7/1986. (VII. 27.) ÉVM-rendelet, majd az ezt módosító 18/1984. (XII. 13.) ÉVM-rendelet a külterületi nyomvonalas létesítmények múszaki nyilvántartásba vonásához szerint az ásvány-vagyonvédelmi érdekek megfelelő érvényre juttatása érdekében meg kellett keresni a KFH-t. A gázenergiáról szóló 1969. évi törvény végrehajtására kiadott 1/1977. (IV. 6.) NIM-rendelet 18. (4) szerint gázvezeték-építési tilalom alól az országos ásványvagyon-nyilvántartásban lévő nyersanyagkészletet tartalmazó területre a KFH-val egyetértésben a bányahatóság felmentést adhatott. A 12/1969. (III. 11.) kormányrendelet a földmérési és térképészeti tevékenységről végrehajtására kiadott 6/1969. (III. 11.) MÉM-rendelet 35. §-a a bejelentés köteles földtani és geomorfológiai térképek meghatározásának, és a gravitációs térképek minősítésének jogát telepítette a KFH-ra.

A KFH a múködése során kiadott közel száz olyan utasítást, amelyek a földtani kutatás szinte minden aspektusát szabályozták. Ezek a normák beivódtak a hazai földtani és bányászati kutatások gyakorlatába, a mai napig alkalmazzák ezeket, gyakran nem is tudatosan. Ez javarészt FüLÖP József érdeme, aki 1969 és 1984 között volt a KFH élén.

FÜLÖP József az NDK-ban múködő területi földtani szervek mintájára 1969. június 13-i KFH-utasításban rendelkezett „A területi/megyei földtani csoportok feladata és ügyrendje" köréről, majd a 6/1972. (X. 5.) KFH-utasítás a szolgálatok ásványvagyon-gazdálkodási és ásványvagyonvédelmi feladatait rögzítette. 1969 és 1975 között kialakult a Területi Földtani Szolgálatok rendszere, Salgótarján, Pécs, Veszprém, Sopron, Szeged, Debrecen és Budapest székhellyel, három, illetve két megyére kiterjedó illetékességgel a jelenlegi EU NUTS2 régióknak megfelelő felosztásban. A 
szolgálatok a Földtani Intézet keretében múködtek, ugyanakkor a KFH területi földtani szerveiként funkcionáltak elsőfokú hatósági, szakhatósági és szakvéleményező jogkörrel. Feladatuk volt a kapcsolattartás a megyei szintú szervekkel, nyilvántartották a területükön felkutatott ásványi nyersanyagokat, évente összeállították az építóipari ásványvagyon-katasztert, ellátták a földtani kutatások felügyeletét, megyei komplex területprognózis térképeket készítettek a megyei településfejlesztést és területrendezést segítendő. A bányatörvény végrehajtásával kapcsolatos eljárásokban a KFH átruházott hatáskörében a szövetkezeti bányászat területén megkutatottsági nyilatkozatot adtak ki, szakhatósági állásfoglalást adtak bányanyitási és bezárási ügyekben, a szabad területek kutatásai alapján a kitermelések engedélyezéséhez, elbírálták a kutatási zárójelentéseket. és azok ásványvagyonszámítását az OÁB elé terjesztették. Engedélyezték az építôipari ásványi nyersanyagok kutatási kérelmeit, ellenőrizték ezek végrehajtását, részt vettek illetékességi területükön a védetté nyilvánítási eljárásokban, rendezési tervek elfogadásában, hulladéklerakó létesítési engedélyezésekben.

\section{A rendszerváltás utáni évek, Magyar Geológiai} Szolgálat (1993-2006)

Az 1990-es politikai és gazdasági fordulatot követôen sor került a bányászati és földtani szakigazgatás reformjára is. Az 1993. évi XLVIII. törvény a bányászatról az ún. nyílt területeken engedély, a zárt területeken koncessziós szerződés alapján teszi lehetővé az ásványi nyersanyagok kutatását és kitermelését. Az elsô fokú bányahatósági feladat- és hatáskört a bányakapitányságok (Szolnok, Miskolc, Veszprém, Pécs) látták el, az általános másodfokú hatóság a Magyar Bányászati Hivatal (MBH) volt.

A földtani intézményrendszer átszervezésének fókuszában a KFH volt, amely a piacgazdaság bevezetésével „szüikségtelenné vált". Az első javaslatot a Magyar Geológiai Szolgálat (MGSZ) létrehozásáról, feladat- és hatásköréről 1991 márciusában a KFH akkori megbízott elnöke nyújtotta be. Az új szervezet tevékenységi körének lehatárolását TELEKI P. kormánytanácsadó beadványára 1991. november 27-én készítette el az Ipari és Kereskedelmi Minisztérium (IKM). Eszerint a Földtani Intézet bázisán egy egységes, KFH-t és ELGI-t magába olvasztó Magyar Földtudományi Intézet jött volna létre. A tervezetet szakmai körökben kedvezőtlenül fogadták, ezért az ipari miniszter új koncepció kidolgozását szorgalmazta. Ezt a KBFI igazgatója vetette papírra 1992. január 20-i miniszterhez intézett levelében, a fentiek és a KBFI közalapítványba integrálását szorgalmazva.

A bányatörvény vitái során az Országgyưlés Környezetvédelmi Bizottságában végül sikerült elfogadtatni a Magyar Geológiai Szolgálat felállítására vonatkozó koncepciót. Az MGSZ-t az 1993. június 12-én hatályba lépett 1993. évi XLVIII. törvény a bányászatról hozta létre, amelynek , $A$ bányászat állami felügyelete” címú IV. részében a „Magyar Geológiai Szolgálat” címú 48. §-a szerint „Az állam földtani, földtani kutatási feladatait, valamint az ásványvagyon gazdálkodással összefüggó feladatokat, önálló költség- vetési intézményként, a Magyar Geológiai Szolgálat látja el." A bányatörvény és a végrehajtására kiadott 115/1993. (VIII. 12.) kormányrendelet további tíz helyen nevesíti az MGSZ-t. 1993. október 14-én lépett hatályba a 132/1993. (IX. 29.) kormány MGSZ statútum rendelet. Az MGSZ Szervezeti és Múködési Szabályzatát az ipari és kereskedelmi, valamint a környezetvédelmi és területfejlesztési miniszter közösen hagyta jóvá.

Az MGSZ önálló feladat- és hatáskörrel rendelkező központi hivatal volt, amelynek keretében múködött a Földtani Intézet és a Geofizikai Intézet részben önálló gazdálkodású költségvetési kutatóintézetként, a gazdasági ügyeket a közös Gazdasági Hivatal végezte. A fóigazgató mellett a tárcák képviseletében Földtani Tanács múködött. A Földtani és a Geofizikai Intézet Adattáraiból az MGSZ Információs Központját alapították meg. A Földtani Intézet Területi Földtani Szolgálatai pedig az MGSZ Területi Hivatalai lettek változatlan területi illetékességgel.

A statútum szerint: „A földtani szakhatósági jogköröket elsó fokon a Magyar Geológiai Szolgálat területi hivatalai, másodfokon a Magyar Geológiai Szolgálat Központi Hivatala látja el." A Központi Hivatalt végül nem hozták létre, helyette Szakhatósági Fóosztály alakult. Az MGSZ sajátos alakulat volt a hazai közigazgatás palettáján, egy hatóság, amely jellegében inkább szakhatóság volt, az engedélyezési eljárások döntő hányadában szakhatóságként vagy szakvéleményezóként vett részt. Tényleges hatósági hatásköre volt az Országos Ásványvagyon Nyilvántartása, amelynek azonban nem volt meg a „közhitelúség” minden attribútuma; a földtani és geofizikai adatok gyújtése és szolgáltatása; a földtani szakértôi engedélyek kiadása; valamint 1997-től a nukleáris létesítmények alkalmasságának vizsgálatára irányuló földtani kutatások engedélyezése.

Az MGSZ megalakulásával egyidejúleg megalakuló MBH-hoz került a KFH nyersanyagkutatást és kitermelést felügyelő jogköre, nem kis részben EszTó Péter elnök érdekérvényesító képességének köszönhetôen: „A hol a jogszabály a Központi Földtani Hivatal vagy a területi földtani szolgálat hatósági vagy szakhatósági jogkörét jelöli meg, ott azásványi nyersanyagok kutatása, feltárása és kitermelése, valamint az ásványi nyersanyag-gazdálkodás és -védelem vonatkozásában a Magyar Bányászati Hivatalt, illetve elsôfokú szerveit (kerületi bányakapitányságok) kell érteni.” A szakhatóság hatásköri spektrumot jól jellemzi az I. táblázat.

Az MGSZ 13 éves története során az eljárások számát tekintve sikeres volt (lásd 2. ábra), a megkeresések száma folyamatosan nőtt, igaz, hogy ez részben a 2008-as válságig tartó gazdasági növekedéssel is magyarázható. Az együttmúködés az MBH-val jó volt, bár a „kötelezően bevonandó szakvéleményezô" státusz hordozott magában potenciális konfliktust. Az MGSZ-nek jó volt a kapcsolata a két intézettel, a finanszírozási nehézségeket nagyban enyhítette a kis- és közepes aktivitású radioaktív hulladékok földtani elhelyezésére irányuló kutatási projektben való részvételük. Ennek kapcsán azonban felvetődött kritikaként a hatóság és a kutatás szervezeti összefonódása mint a piaci versenyt veszélyeztető, összeférhetetlenséget jelentő tényező. A nukleáris ágazat terü- 
1. táblázat Az MGSZ szakhatósági és szakvéleményezői feladatai

Table I. The list of co-authority mandates and professional opinion roles of MGSZ

Szakhatósági tevékenységről rendelkező jogszabály

A külterületi nyomvonalas jellegü létesítmények engedélyezéséhez szakvélemény készítése a 7/1986. (VII. 27.) ÉVM-rendelettel módosított 18/1984. (XII. 13.) ÉVM-rendelet és a 132/1993. (IX. 29.) kormányrendelet

A természeti terület védetté nyilvánítás szakhatósági tevékenysége a természet védelméröl szóló 1982. évi 4. tv. és a végrehajtására kiadott 8/1982. (III. 15.) MT-rendelet és a 132/1993. (IX. 29.) kormányrendelet alapján

Atomerőművi és radioaktív hulladékelhelyezéssel kapcsolatos (elhelyezés, mütárgy létesítése, üzembehelyezése, üzemeltetése, átalakítása, javítása, megszüntetése) szakhatósági eljárás (tervezés, döntéselőkészítés, engedélyezés) az atomenergiáról szóló 1980. évi I. tv. végrehajtásáról rendelkező 7/1988. (VII. 20.) SZEM-rendelet és a 132/1993. (IX. 29.) kormányrendelet alapján

Az általános rendezési tervek elfogadásának szakhatósági eljárása a 7/1983. (Ép. Ért. 23.) ÉVM utasítás és a 132/1993. (IX. 29.) kormányrendelet alapján

A területgazdálkodási és területfejlesztési tervek kialakításának szakhatósági tevékenysége a területrendezési tervek elkészítésének, egyeztetésének, jóváhagyásának, karbantartásának és módosításának rendjéről szóló 7/1983. (Ép. Ért. 23.) ÉVM-utasítás, valamint a 2/1986. (II. 27.) ÉVM-rendelet Országos Építési Szabályzatról és a 132/1993. (IX. 29.) kormányrendelet alapján

Gyógybarlangok létesítéséhez, fenntartásához, tervezéséhez, átalakításához és megszüntetéséhez szakvéleményező tevékenység a 132/1993. (IX. 29.) kormányrendelet és a 7/1986. (VII. 10.) EüM-rendelet

Az elismert ásvány-, illetőleg gyógyvíz, továbbá a gyógyászati célú hévíz engedélyezési eljárásához szakvéleményező tevék enység az egészségügyről szóló 1972. évi II. törvény és a végrehajtására kiadott 7/1986. (VII. 10.) EüM rendelet és a 132/1993. (IX. 29.) kormányrendelet alapján

A területfelhasználási engedélyezéssel kapcsolatos szakhatósági eljárás a 21/1994. (VI. 29.) KTM-rendelettel módosított 1/1968. (I. 11.) ÉVM-rendelet alapján

Telekalakítási eljárásokkal kapcsolatos szakhatósági tevékenység a 21/1994. (VI. 29.) KTM-rendelettel módosított 29/1971. (IX. 29.) ÉVM-rendelet alapján

Építési és használatbavételi engedélyezési eljárásokkal kapcsolatos szakhatósági tevékenység a 21/1994. (VI. 29.) KTM-rendelettel módosított 12/1986. (XII. 30.) ÉVM-rendelet alapján

Az ásványvagyon-kutatási tervek, munkaprogramok elfogadásához szakvélemény készítése a XLVIII/1993. törvény és a 132/1993. (IX. 29.)

kormányrendelet alapján

A bányatelek megállapításával, a bánya tartós szüneteltetésével vagy bezárásával kapcsolatos szakvélemény készítése a XLVIII/1993. törvény és a 132/1993. (IX. 29.) kormányrendelet alapján

Az MBH hatósági jogkörébe utalt földtani feladatokhoz szakvélemény készítése a XLVIII/1993. törvény és a 132/1993. (IX. 29.) kormányrendelet alapján

A 100 kV-nál nagyobb feszültségü villamosvezetékek vezetékjogi engedélyezési eljárásában a 17/1968. (IV. 28.) NIM-rendelet alapján szakhatóság állásfoglalás

Vasúti építmények engedélyezési eljárásában a 15/1987. (XII. 27.) KM-ÉVM együttes rendelet alapján szakhatósági állásfoglalás

A közcélú vízvezetéki ivóvízellátásra szolgáló víznyerő helyek védőterület kijelölési eljárásában a 11/1961. (VE. 8.) EüM-0VF együttes utasítás alapján szakvélemény

A örnyezeti hatásvizsgálat köteles tevékenységek környezetvédelmi engedélyezési eljárásában szakterületét érintő kérdés felmerülése esetén a $152 / 1995$. (XII. 12.) kormányrendelet alapján szakhatósági állásfoglalás

Hulla(dék) temetők, hullaemésztő -vermek és hullaégetők létesítési eljárásában a 28/1981. (XII. 30.) MÉM rendelet az Állategészségügyi Szabályzat kiadásáról alapján

A tájrendezési terv elkészítésére és megalapozását szolgáló kutatásokra vonatkozó finanszírozási igények engedélyezésében a 26/1994. (VII. 14.) KTMrendelet alapján

letén ekkoriban születetett a 170 év talán legspecifikusabban földtani követelményeket taglaló jogszabálya (62/1197. [XI. 26.] IKIM-rendelet), ez alapján kapott engedélyt az ország első felszín alatti radioaktív hulladék elhelyezési létesítménye, valamint más nukleáris létesítmények is.

Az 1033/1995. (IV. 28.) és a 1105/1995. (XI. 1.) kormányhatározatok rögzítették a területi közigazgatás re- formjának fő irányait (VEREBÉLYI 1996). Ezeket továbbiak követték (1027/1996. [IV. 3.] és az 2171/1996. [VII. 10.] kormányhatározat), amelyek nem érintették az MGSZ-t, egészen 2006-ig, amikor a 267/2006. (XII. 20.) kormányrendelet az MGSZ (és a Szénbányászati Szerkezetátalakítás Központ) MBH-ba történő beolvasztásáról rendelkezett. 


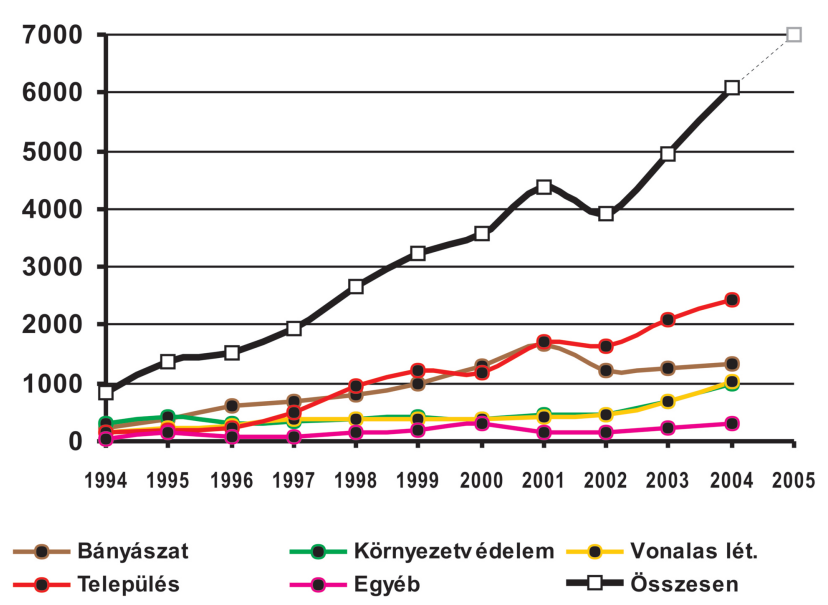

2. ábra. Az MGSZ szakhatósági eljárásai számának változása 1994-2005 között Figure 2. The time series of the co-authority procedures of MGSZ between 1994 and 2005

Az egyesült bányászati és földtani hatóság, Magyar Bányászati és Földtani Hivatal (2007-2017)

Az MBFH létrejöttének volt közigazgatási, finanszírozási és szakmai racionalitása, de a fúzió veszteségekkel is járt. A földtan és a bányászat történelmileg és szakmailag összetartozó, de az utolsó 100-150 évben a földtan alkalmazási köre számos új területtel bővült, a bányászat érdekeivel szemben állókkal is. Az MBH 2005-től az általa beszedett bányajáradékból finaszírozta magát sikerrel, „felügyeleti díj” jogcímen, míg az MGSZ és intézetei az állami finaszírozás és a piaci bevételek között lavírozva is csak nehezen tudták megőrizni múködőképességüket. A földtan az integráció után teljesebb hatósági eszközrendszerrel és talán valamelyest erôsebb érdekérvényesítéssel tudott fellépni egyes ügyekben, pl. nyersanyagkutatás, ásványvagyon-gazdálkodás, geotermikus energia kutatás stb. (HÁMOR 2014a).

Az MBFH kezdeti időszakában a jogalkotás expanzív volt, sikerült bevezetni az országos területrendezési törvénybe az ,ásványvagyon-gazdálkodási” és a „földtani veszélyforrás övezetek" fogalmát, a bányajogban részletesebb tárgyalást nyert a geotermika, a bányászati hulladék kezelés, az ipari szén-dioxid elhelyezés, a földtani szakértői engedélyek eljárási rendje. Az előbbi tematikák mellett ekkor bontakozott ki az Európai Unióban a közösségi nyersanyag-politika, és a nem hagyományos szénhidrogének problematikája is (HÁMOR 2016). Az MBFH nemzetközi tevékenysége is kibontakozott, számos szakmai bizottságban képviselve hazánkat Brüsszelben, valamint az ENSZ Fenntartható Bizottság Bányászati Munkacsoportjában az Európai Uniót 2011-ben.

Szintén ebben az idôszakban vetődött fel a koncessziós pályáztatás visszavezetése a gyakorlatba, mert az 19982009 közötti időszak tapasztalatai jelezték, hogy a liberalizált engedélyezés számos hátránnyal jár. Az eltelt kilenc

${ }^{1}$ 1998-ban az MBH elnöke máig vitatott okokból és körülmények között minősitette nyílttá az ország teljes területét minden ásványi nyersanyagra. év sikeres kőolaj- és földgázkutatásai e döntés helyességét igazolják.

Egy szervezet legnagyobb ereje a humán erőforrása, és e tekintetben az integráció jelentős kárt is okozott. Az MGSZ területi hivatalok területi illetékessége és javarészt székhelye sem egyezett a bányakapitányságokéval, ami számos tapasztalt szakember és vezető önkéntes távozását vonta maga után. A területi hivatalok egyben az MGSZ Információs Központ kihelyezett adattárai voltak, amelyek szintén átkerültek a bányakapitányságokhoz, azonban ezek további gondozása és bővítése már nem mindenütt volt prioritás. Központi szinten ezt az attitűdöt jelezte az Építésföldtani és Geotechnikai Adattár átadása a belügyi tárcának.

Két-három „,békeév” után 2010-től ismét változékonyabb lett az állami környezet. A tárca portfólió egyszerúsítésével az MBFH a Nemzeti Fejlesztési Minisztérium (NFM) irányítása alá került, amely tartalmában továbbra is az ipari fejlesztést jelentette. Az irányítási koncentráció szervezeti centralizációval és deregulációval is járt. Ezt megelőzendő a Földtani Intézet tett kérészéletû kapcsolódási kísérletet a környezetvédelmi tárcához, majd visszakerült az NFM-hez. A 320/2011. (XII. 27.) kormányrendelet pontot tett a folyamat végére a Geofizikai Intézetbe olvasztásával 2012. április 1jei hatállyal, így jött létre a Magyar Földtani és Geofizikai Intézet (MFGI). Az MFGI öt és fél évet ért meg, 2017 június 30-án a 161/2017. (VI. 28.) kormányrendelet alapján beolvadt az MBFH-ba, amelynek neve Magyar Bányászati és Földtani Szolgálattá változott (MBFSZ).

Az intézetek (majd MFGI) együttmúködése az MBFHval jó volt, sőt saját, kvázi szakhatósági feladatokkal is bővült funkciójuk, például a VITUKI megszúnésével 60 év után ,visszakerültek” a vízföldtani adatok nyilvántartási feladatai. A koncessziócsomagok tucatjait készítették elő, és javarészt ők gondozták a Ásványi Nyersanyag Készletgazdálkodási és Cselekvési Terv előkészítését is.

A közigazgatási reform 2015-ben újabb lendületet vett, ezúttal a decentralizáció irányába, az EU szubszidiaritás elvének megfelelően, az egyablakos ügyintézést elősegítendő („,one-stop-shop”) április 1-jén a bányakapitányságokat integrálták a kormányhivatalokba (Baranya Megyei, BorsodAbaúj-Zemplén Megyei, Jász-Nagykun-Szolnok Megyei, Pest Megyei, Veszprém Megyei Kormányhivatalok), és a felügyeleti díj meghatározott része is odakerült. A szervezeti átalakítás tovább nehezítette az első és másodfokú hatóság közötti kommunikációt, volt időszak, amikor ez csak a minisztériumon keresztül volt elvileg folytatható. Ez értelemszerúen nem kedvezett az információigényes földtani hatósági munka hatékony végzésének.

\section{A jelen, Magyar Bányászati és Földtani Szolgálat (2017-)}

Az MBFH kormányhivatal, bányafelügyeleti és állami földtani feladatköreinek gyakorlásával összefüggésben a törvényességi és szakszerűségi ellenőrzési hatásköröket szakmai irányító miniszterként a — bányászati ügyekért felelős - az innovációért és technológiáért felelős miniszter gyakorolja. 
A kormányhivatal bányafelügyeleti hatáskörébe tartozó közigazgatási hatósági ügyekkel összefüggésben meghatározott hatásköröket, a fellebbezés elbírálására jogosult hatóság feladatait az MBFSZ gyakorolja.

A bányafelügyelet hatáskörébe tartozó hatósági ügyekben néhány kivétellel elsô fokon a kormányhivatal jár el. Az MBFSZ országos illetékességgel jár el, döntése közigazgatási perben támadható meg. Az MBFSZ fontosabb, földtani vagy földtani közremúködést igénylő elsőfokú hatósági jogkörei a teljesség igénye nélkül, (részletesen 1. 161/2017. [VI. 28.] kormányrendeletben):

— szénhidrogének felszín alatti tárolására bányatelek megállapítása,

— szén-dioxid geológiai tárolásával összefüggő hatósági eljárások,

— geotermikus védőidom kijelölése és ehhez kapcsolódó nyilvántartás,

— földtani szakértői nyilvántartás,

— kutatási területek, bányatelkek, mélyfúrások, bányászati hulladékkezelő létesítmények nyilvántartása,

— ásványi nyersanyag és geotermikus energiavagyon nyilvántartás vezetése, és az ebből történő igazolás kiadása,

— földtani adatszolgáltatások kezelése.

Némi elhanyagolással, ez a lista jobban emlékeztet az egykori MGSZ hatásköreire, mint a közvetlen jogelőd MBFH-éra.

Az MBFSZ Szervezeti és Múködési Szabályzatát a 37/2019. (X. 4.) ITM utasítás rögzíti.

\section{Diszkusszió}

A tárgyilagosságra való tudatos törekvés ellenére a fenti rövid történelmi áttekintés 170 évről óhatatlanul a szerző saját véleményét is tükrözi az eltérô hangsúlyokkal. Ezt csak egy szerzői kollektíva terjedelmes monografikus múve tudná kiküszöbölni. Az l. ábrán vázolt történelmi ív azonban az alábbi megfontolások rögzítésére adhat alapot.

A földtan intézményesülésének kezdeteitôl, a 19. század közepétől szereplője az állami döntéselőkészítésnek és végrehajtásnak, tágabb értelemben az államigazgatásnak. A klasszikus közigazgatási szerep akkortól datálható, amikor már rendelkezett külön főhatósággal, szúk értelemben vett engedélyezési hatáskörrel, majd elsô fokon eljáró területi szervekkel.

A nagyobb államigazgatási szektorokhoz való tartozás vonatkozásában megállapítható, hogy az állami földtani intézmények az agrár és ipari tárca, majd agrár, majd 1935tól az ipari tárca irányítása és felügyelete alatt tevékenykedtek, bármi is volt a minisztérium tényleges neve (ipari és kereskedelmi/közlekedésügyi/energiaügyi/bányászati/ idegenforgalmi). Ez alól rövid idejú kivételt jelentett a Pénzügyminisztérium a Geofizikai Intézet vonatkozásában, és a Minisztertanács az OFF múködése idején. A felügyelet kérdése időről idôre felvetődött a késôbbiekben is (pl. az Országgyúlés alá rendelés), de ennek nem volt realitása a hazai hagyományok és a nemzetközi evidenciák alapján sem.
Van jelentôsége annak is, hogy az irányító szervnél vane elkülönült fóosztály, osztály, esetleg helyettes államtitkárság a szakterületre specializálódva. 1910-tôl ilyen szinte folyamatosan létezett bányaföldtan, földtan, energetika megnevezéssel.

A szúk közigazgatási értelemben vett tényleges földtani hatóság az OFF megalakulásához datálható, és jogfolytonosan létezik máig. Az egyes földtani hatóságok regnálásának időtartama, átszervezéseik időbeli dinamikája elsôsorban a nagyobb történelmi-politikai változásokkal korrelál. Ebből a szempontból nem meglepő, hogy a KFH 24 éves fennállása a Kádár-korszakban kétszer-háromszor olyan hosszú, mint a többi jogelőd és jogutód 8-13 éves múködése. Ilyen szempontból is sajnálatos esemény volt az államigazgatást 143 éven át támogató Földtani Intézet integrációja, valamint az első fokú szervek, a 37 évet megért területi földtani szolgálatok beolvasztása a kormányhivatalokba. Meg kell jegyezni azonban, hogy ez utóbbi vonatkozásában az „egyablakos” hatósági modell megfelel a nemzetközi és az európai trendnek. Az elmúlt negyedszázad történései vonatkozásában nehéz nem megállapítani, hogy a földtan jelentôs mértékben osztozik sorsában a bányászattal, igaz, hogy hazánkban a környezetvédelmi és vízügyi intézményrendszer sem mutathat fel nagyobb és időtállóbb eredményeket. Ennek kifejtése azonban már egy másik tanulmány tárgya lehetne.

A földtani hatáskörök, a földtani szakhatósági közremúködés, az állami földtani feladatok teljes körú évenkénti változásainak ismertetése és elemzése meghaladja a tanulmány terjedelmi korlátait. A 3. ábra kísérletet tesz ennek leegyszerúsített, de számszerú bemutatására, amely a jogalkotás révén egyben tükrözi a földtan államigazgatási és talán társadalmi elismertségét is. A 3. ábra a) azt mutatja, hogy 1989 és $2019^{2}$ között az adott évben hány olyan jogszabály jelent meg, amely tartalmazza a „földtan”, ,geológia” vagy „ásvány” szavakat bármilyen ragozott formában és bármilyen kontextusban, bármilyen jogforrási szinten. Némi elhanyagolással ez megfeleltethetố a szakma jogszabályi meghatározottságával, amely folyamatosan nőtt 2012ig, egy hasonló csúccsal 2006-ban. Érdekes módon az első csúcs egybeesik az MBFH megalakulásával, a második pedig a teljes intézményrendszer integrációjának kezdetével. A tényleges hatásköri lista bővülése ezzel nem egyenlő, de vélelmezhetően ezzel jól korrelál.

Meg kell említeni, hogy a hazai jogalkotás egyik motorja 2004-tôl az Európai Unió közösségi jogának való megfelelés. E szempontból a Közösség a környezetvédelem, a nyersanyag-gazdálkodás, az energetika és a vízgazdálkodás területén számos olyan irányelvet és határozatot fogadott el, amelyeket átültette a hazai jogba. Ezeket a szerzô számos munkája ismerteti, valamint az EU Nyersanyag Információs Rendszere is szolgáltatja (https://rmis.jrc.ec.europa.eu/).

Lényegében ezzel egyező képet mutat a 3. ábra b), amely a fenti fogalmak előfordulását vizsgálja az adott évben hatályos törvényekben, hat fontos évben, amelyek egy-

\footnotetext{
${ }^{2}$ A lekérés pontos időpontja 2019. szeptember 9.
} 


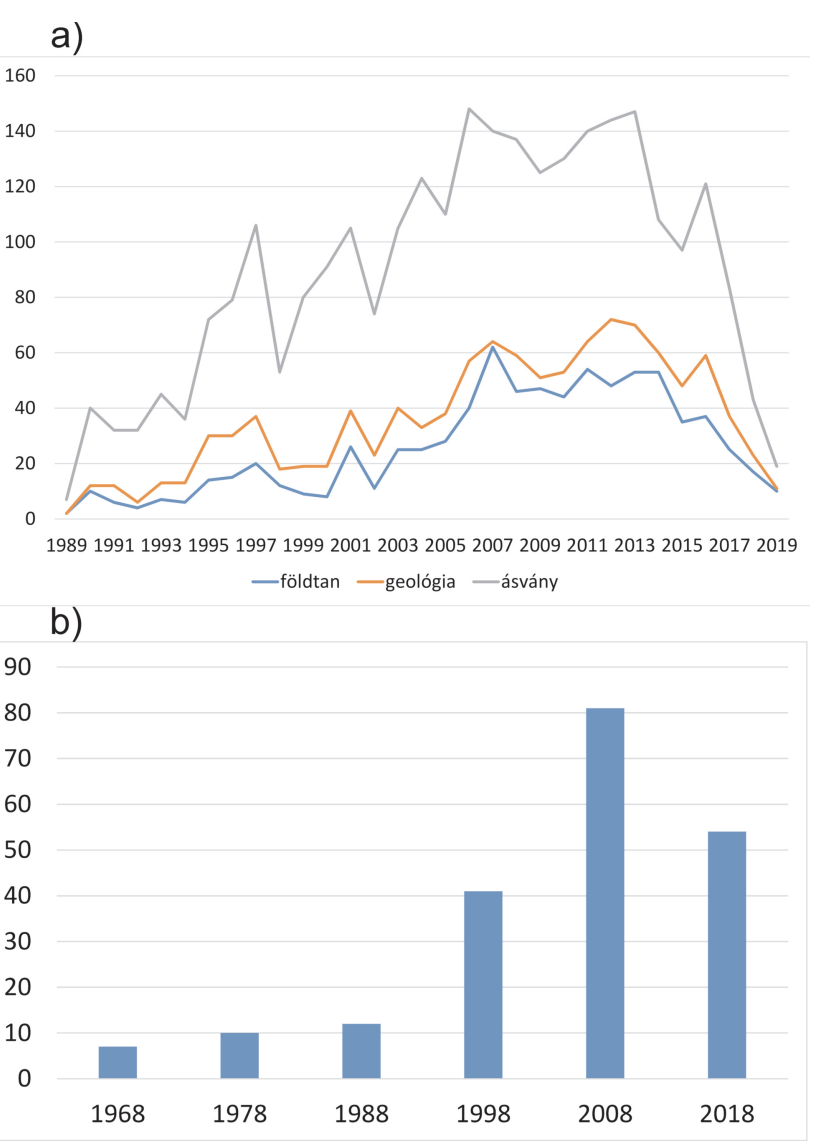

3. ábra. a) A „földtan”, „geológia”, „ásvány” szavak megjelenése a hazai jogszabályokban 1989 és 2019 között (2019 csak az első 3/4 év adataival). b) A „földtan”, ,geológia” vagy „ásvány” szavak megjelenése az adott évben hatályos magyar törvényekben hat időkivágatban

Figure 3. a) The occurrence of terms "geology” and "mineral" annually in the Hungarian legislation between 1989 and 2019 (in 2019 the first three quarters were examined). b) The occurrence of terms "geology" and "mineral" in the Hungarian acts in force in six representative years beesnek az akkori földtani hatóságok múködésének kiteljesedésével. A csúcs itt is 2008-ra, azaz az MBFH tevékenységének időszakára esik.

Az egyes szakmai hatásköri tematikák időbeli változása (4. ábra) egyéni értékelést tükröz, ennek részletes bizonyítása hosszasabb kutatást és adatbázist igényelne. A nagy trendek azonban talán kevéssé vitathatók. A kezdetekben meghatározó volt az agrogeológiai és ásványi nyersanyagkutatási tevékenység, de ez igen hamar, az 1880-as évektől kibővült a vízügyi és építésügyi tevékenységekkel. A talajtan 1948-tól vált ki a Földtani Intézet feladatköréből, a vízügyek egy része pedig 1956-tól.

A geofizika vonatkozásban az 1881-től a földrengésmegfigyelés és a földmágnesség mérése tekinthető az első állami feladatnak, majd a 20. század elejétől az Eötvös-féle gravitációs mérések.

A KFH megalakulásával, a hatvanas évek végétől a hatásköri lista tovább nőtt a területrendezési tervek véleményezésével a földmérési és térképészeti területen, majd 1980tól a nukleáris ügyekben. 1971-től indult a földtani szakértői engedélyek kiadása, amely figyelemreméltóan progresszív a nem piacgazdasági keretek között. A hazai természetvédelem nagy és korai hagyományokkal bír (BÁNDI 1995), a földtan részvétele 1949-tól datálható. A környezetvédelmi és természetvédelmi szakigazgatási eljárások és ebben a földtani szakhatósági részvétel az 1990-es évektől jelentettek új kihívásokat. Az MGSZ múködése idején azonban mind a bányászati, mind a környezetvédelmi ügyeket meghaladta az építésügyi, területfejlesztési és településrendezési eljárások száma (2. ábra).

Az EU-csatlakozás számos új szakterületet hozott a földtani szempontok szakhatósági-hatósági érvényesítésével (HÁMOR 2002, HÁMOR \& FARKAS 2012). Ez a települési és veszélyes hulladékok lerakása, szén-dioxid elhelyezés, bányászati hulladék kezelése és a felhagyott létesítmények

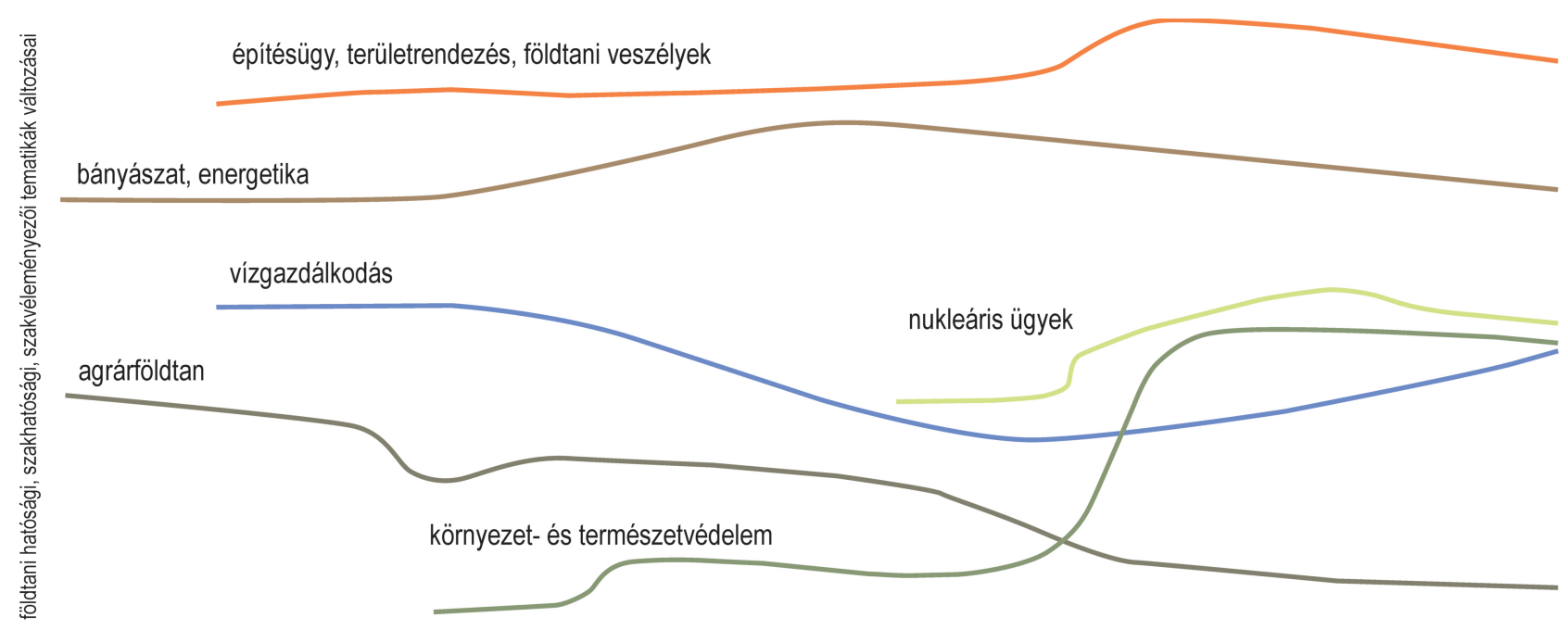

$1848 \quad 1869 \quad 1907 \quad 1935$

1848

19641969

1993

$2007 \quad 2012 \quad 2015 \quad 2017$

4. ábra. A földtani hatósági, szakhatósági, szakvéleményezői tematikák becsült változásai (a vízszintes tengelyen az időlépték nem egyenközű)

Figure 4. Historical trends of the thematics in scope of the geological authority(ies) in Hungary (please note that the time scale on the horizontal axis is not equant) 
felmérése, radioaktív hulladékok elhelyezése, geotermikus energia kutatása, hagyományos szénhidrogének kutatása és kitermelése, nem hagyományos szénhidrogének kutatása és kitermelése rétegrepesztéssel, nyersanyag-politika kialakítása, dekarbonizáció és ezzel összefüggésben az állami támogatású szénbányák bezárása, földtani veszélyforrások felmérése.

A fentiek olvasatában megállapítható, hogy a földtani feladatoknak az európai földtani szolgálatok által 1998-ban publikált csoportosítása ma is helytálló (HÁMOR 2002):

„Georesources" — a földtani természeti erőforrások (ásványi nyersanyagok, geotermikus energia, felszín alatti vizek, földi erőterek);

„Geospace” — a földtani közeg hasznosítási lehetőségei (hulladékelhelyezés, vonalas és más létesítmények, tárolás, föld alatti laboratóriumok stb.);

„Geoenvironment” — a földtani környezet- és természetvédelmi tevékenységek;

„Geohazards" - a földtani környezetnek az emberre és épített környezetére veszélyes adottságai és folyamatai (földcsuszamlások, földrengések, vulkánkitörés stb.).

A cikkben foglalt nagyobb történelmi ív felvázolása alkalmat adhatna a jövőbeli kitekintésre is, ezt azonban a szerző az olvasókra bízza.

\section{Következtetések}

Történelmi léptékben az intézményesített földtan 170 éve van jelen Magyarországon, a kezdetektől fogva támogatva az államigazgatást, majd a 20. század közepétôl külön hatóságként a hazai közigazgatást. A hatósági és szakhatósági jogkörök aránya és tematikája folyamatosan változott, csakúgy mint a kérdéses intézmények neve, szervezete és jogállása. Ez utóbbi jól tükrözi a tágabb politikai kontextus időbeli változásait is. A centralizáció-decentralizáció dilemmája végig jelen van a hazai közigazgatás történetében, azonban a földtan esetében, amely jelentôs adat- és információigényű, az első és másodfokú földtani hatóság kommunikácójának és munkakapcsolatának gyengülése, az információszolgáltatási képességek csökkenése nehezítheti a hatékony és ügyfélbarát ,jó kormányzást”. Ugyanakkor az első fokon eljáró földtani hatóság kormányhivatali integrációja összhangban van az Európai Unió szubszidiaritási elvével és a „jó kormányzás” egyablakos eljárási modelljével. A földtan jogszabályi ,beágyazottsága” az elmúlt évtizedek szakmai jogalkotói munkájának és az Európai Uniós közösségi joga átültetésének köszönhetően jó, 2008-2012-ig folyamatosan nőtt. Ezt, és a végrehajtás intézményi eszközrendszerét megóvni ésszerû szakpolitikai cél lehet.

\section{Köszönetnyilvánítás}

A szerző e rövid tanulmánnyal szeretne adózni mindazon kollégáknak, akik hittek a földtan államigazgatási szerepében, és elkötelezetten végezték munkájukat a társadalmi és gazdasági hasznosulás reményében. Köszönet illeti azokat a nem hatósági geológus és geofizikus kollégákat is, akik felismerték, hogy mindennapi kenyerük részét vagy egészét tevékenységük jogszabályi meghatározottságának és e rendelkezések hatósági „kikényszerítésének” köszönhetik.

A szerző külön köszönetét fejezi ki Dr. CzINE Ágnes alkotmánybírónak, aki a jogtörténeti kutatásban pótolhatatlan segítségére volt, valamint Dr. BREZSNYÁNSZKY Károly és Dr. HALMAI János bírálóknak, akik értékes észrevételeikkel javították a kézirat minőségét és tárgyilagosságát.

\section{Irodalom - References}

BÁNDI Gy. 1995: A környezet védelmének joga. — Kézirat, egyetemi jegyzet, ELTE Jogi Továbbképző Intézet, Budapest, 43 p.

BöcKH J. \& SzOnTAGH T. 1900: A Magyar Királyi Földtani Intézet. — Franklin Társulat Nyomdája, Budapest, 66 p.

BREZSNYÁNSZKY K. 2019: Emlékezzünk a 150 éve alapított Földtani Intézetre! — In: BudAi T., PALOTÁs K. \& PIROs O. (szerk.): Vándorgyúlés a Magyar Királyi Földtani Intézet jubileuma és az Eötvös Loránd Emlékév tiszteletére. — MFT, MGE, Budapest, 7-10.

Dudich E. 1994: A Magyar Állami Földtani Intézet 125 éve. — Természettudományi Közlöny 125/9, 387-391.

FüLöP J. 1984: Az ásványi nyersanyagok története Magyarországon. — Múszaki Könyvkiadó, Budapest, 179 p.

FÜlÖP J. \& TASNÁdi KuBACSKA A. (szerk.) 1969: 100 éves a Magyar Állami Földtani Intézet. — MÁFI, Budapest, 274 p.

HÁla J. (szerk.) 1994: 125 éves a Magyar Állami Földtani Intézet, Tanulmányok. — MÁFI, Budapest, 180 p.

HÁmOR T. 1996: A földtani intézményrendszer szerepe a magyar közigazgatásban. — Kézirat, Szakdolgozat, Eötvös Loránd Tudományegyetem, Jogi Továbbképző Intézet, 56 p.

HÁMOR T. 1999: Jogharmonizáció, csatlakozás, földtani kutatás. — Földtani Kutatás 36/3, 44-45.

HÁMOR T. 2002: A Magyar Geológiai Szolgálat az uniós csatlakozás küszöbén: Elemző összehasonlítás az EU tagállamok földtani szolgálataival. — Földtani Kutatás 39/3, 41-49.

HÁmor, T. 2004: Sustainable mining in the European Union: The legislative aspect. — Environmental Management 33, 252-261.; JRC Publication $\mathrm{N}^{\circ}$ : JRC23122; https://link.springer.com/article/10.1007/s00267-003-0081-7

HÁmor T. 2014a: Jogszabályi keretek, engedélyeztetés. — In: PÁL-Molnár E. \& Bíró L. (szerk.): Szilárd ásványi nyersanyagok Magyarországon. - Szeged, Geolitera, 205-228.

HÁMOR, T. 2014b: Legal duties of eurogeologists in the past, and future vision according to the ERA-MIN Roadmap. — EFG Workshop "Geologists of Europe in the $3^{\text {rd }}$ Millenium", Palermo, Programme and Abstracts, p. 8. 
HÁMOR, T. 2016: Geology, the regulated discipline in Europe — a historical review and a vision. - 35 ${ }^{\text {th }}$ International Geological Congress, Cape Town, Abstracts; https://www.americangeosciences.org/sites/default/files/igc/508.pdf; https://www.americangeosciences.org/ information/igc?page $=25$

HÁMOR T. \& FARKAS I. 2012: A földtani kutatás és a földtani közeg hasznosítás szabályozása és állami felügyelete. — Földtudományi és Környezetvédelmi Vándorgyúlés és Kiállitás, Miskolc, Absztrakt kötet, 47-48.

HÁMOR T. \& REZESSY G. 1997: A földtani szakigazgatás szerepe a földtani kutatásban. — Földtani Kutatás 34/1, 17-19.

HÁMORNÉ VIDó M. 2002: A hazai szerves kőzettan elsố száz éve. — Földtani Közlöny 132, 265-287.

Izsó I. 2010: A magyar bányajog fejlődésének átmeneti korszaka. — Miskolc, https://mek.oszk.hu/09000/09009/pdf/banyajog1.pdf

Izsó I. 2019: A bányahatóság története Magyarországon. — Magyar Bányászati és Földtani Szolgálat, Budapest, 132 p.

MorvaI G. 1992: A Központi Földtani Hivatal földtani, államigazgatási és hatósági tevékenysége, A KFH tevékenysége az $1964-1991$. években. - Kézirat, Országos Földtani és Geofizikai Adattár, Budapest, T. 17014. I., 58 p.

NÉMETH J. 1993: Új magyar bányajog. — Novorg, Budapest, 157 p.

TÁRKÁNY SzỨcs E., RADNAY J. \& KISS L. 1970: Magyar bányajog. — Közgazdasági és Jogi Könyvkiadó, Budapest, 735 p.

Vendl A. 1958: A százéves Magyarhoni Földtani Társulat története. — Tankönyvkiadó, Budapest, 276 p.

VEREBÉLYI I. 1996: A kormányzás és a közigazgatás reformjának tervezete. —Magyar Közigazgatás 46/4, 193-229.

Vörös K., Boreczky B., Máté G., MüLler V. G. \& VASS, I. (szerk.) 1985: A magyar állam szervei 1944-1950. — Közgazdasági és Jogi Könyvkiadó, Budapest, I-II., 863 p.

ZELENKA T. 1993: A magyarországi állami földtani-geofizikai kutatások története (1868-1949). — Földtani Közlöny 123/1, 99-105.

ZsÁMBOKI L. 1982: Az országos bányajog és bányaigazgatás fejlődési iránya Magyarországon a honfoglalástól az I. világháború végéig. - A Nehézipari Mû́szaki Egyetem Központi Könyvtárának Kiadványai 20, 167-196.

ZsARNAI S. (szerk.) 1986: A bányahatósági igazgatás. — ELTE Jogi Továbbképző Intézet, Budapest, (Jegyzet), I-II kötet, 398 p.

Kézirat beérkezett: 2019. 09. 09. 
